\title{
EFEKTIVITAS PEMANFAATAN RUANG DI PROVINSI JAWA BARAT (STUDI KASUS PLTP GUNUNG CIREMAI DAN PLTU I CIREBON)
}

\author{
The Effectiveness of Space Utilization in West Java \\ (Case Study on Ciremai Mountain Geothermal Power Plant and Cirebon Steam Power Plant)
}

\author{
Canggih Prabowo \\ Fakultas Hukum Universitas Katolik Parahyangan \\ Jl. Merdeka No. 30 - Bandung \\ Email: canggihprabowo@gmail.com
}

Naskah diterima: 16 Juni 2017; revisi: 2 Agustus 2017; disetujui: 22 Agustus 2017

\begin{abstract}
Abstrak
Salah satu prioritas di dalam Rencana Pembangunan Jangka Menengah 2005-2009 adalah pemenuhan kebutuhan tenaga listrik nasional. Salah satu upaya yang dilakukan adalah dengan pemanfaatan ruang untuk lokasi pembangkit tenaga listrik. Tulisan ini mengangkat permasalahan harmonisasi hukum terkait pemanfaatan ruang kawasan hutan koservasi untuk pembangunan PLTU di Cirebon dan melihat peran serta masyarakat dalam penegakan hukum berkenaan perluasan dari PLTU unit 1 Cirebon. Dengan pendekatan yuridis normatif diketahui pemanfaatan ruang baik di kawasan hutan dan non kawasan hutan pada pelaksanaannya dapat berubah tanpa melakukan revisi atas rencana tata ruang wilayah, jika pelaku usaha telah memperoleh izin lingkungan untuk pembangkit listrik tenaga uap, sedangkan pengusahaan energi panas bumi, pemerintah telah melakukan proses harmonisasi hukum di tingkat peraturan utama dan peraturan pelaksana secara parsial. Di samping itu peran serta masyarakat pemanfaatan ruang untuk pemenuhan tenaga listrik tidak menjadi pertimbangan utama karena lebih mengedepankan capaian program strategis nasional. Oleh karena itu pemerintah perlu melakukan perubahan undang-undang tentang konservasi sumber daya alam dan ekosistemnya, serta perlu mendorong peran serta masyarakat di dalam penataan ruang.
\end{abstract}

Kata Kunci: pemanfaatan ruang, pembangkit listrik, harmonisasi hukum

\begin{abstract}
One of the priorities stated in the National Medium-Term Development Plan 2005-2009 is to provide adequate electricity for national need. This paper raised the issue of how the government efforts to harmonize the law related to space utilization of geothermal energy utilization for the purposes of electric power in the forest area of conservation and how the participation of the community in law enforcement related to the expansion of PLTU unit 1 Cirebon. With the normative juridical approach, it is known that space utilization both in forest area and non-forest area in its implementation is still revamp able without revising the spatial plan if the business actor has obtained the environmental permit for steam power plant. In addition, the participation of public space utilization for the fulfilment of electric power is not a major consideration because it prioritizes the achievement of national strategic programs. Therefore the government needs to make changes to the law on the conservation of natural resources and its ecosystem, and should encourage community participation in spatial planning.
\end{abstract}

Keywords: space utilization, power plant, law harmonization 


\section{A. Pendahuluan}

Dalam perkembangannya pembangunan berkelanjutan tidak sekedar menjadi sebuah konsep semata, namun telah berevolusi menjelma ke dalam kerangka hukum sebagai sebuah asas hukum dan sumber kebijakan utama dari pembangunan di Indonesia. Hal ini didasarkan pada kebutuhan dasar generasi saat ini dan adanya keterbatasan yang timbul akibat kemajuan teknologi serta organisasi sosial terkait kemampuan daya dukung lingkungan guna menopang kehidupan generasi sekarang dan generasi masa depan. ${ }^{1}$

Konsep dan ide pembangunan berkelanjutan tersebut mencakup 3 (tiga) aspek yakni ekonomi, sosial dan ekologi yang oleh Otto Sumarwoto dijabarkan sebagai berikut: ${ }^{2}$

a. Aspek sosial, yakni pembangunan yang berdimensi pada manusia dalam hal interaksi, interelasi dan interdependensi yang erat kaitannya juga dengan aspek budaya. Tidak hanya pada permasalahan ekonomi, pembangunan berkelanjutan untuk menjaga keberlangsungan budaya dari sebuah masyarakat supaya sebuah masyarakat tetap bisa eksis untuk menjalani kehidupan.

b. Aspek lingkungan (ekologi), yakni pembangunan berkelanjutan melalui: a) Terpeliharanya proses ekologi yang esensial; b) Tersedianya sumber daya yang cukup; c) Lingkungan sosial budaya dan ekonomi yang sesuai. c. Aspek ekonomi, merupakan proses perubahan yang terencana, yang di dalamnya terdapat eksploitasi sumber daya, arah investasi orientasi pengembangan teknologi, dan perubahan kelembagaan yang kesemuanya ini dalam keadaan yang selaras, serta meningkatkan potensi masa kini dan masa depan untuk memenuhi kebutuhan dan aspirasi masyarakat.

Selanjutnya ketiga aspek di atas, secara implisit tertuang dalam Pasal $28 \mathrm{H}$ ayat (1), Pasal 33 ayat (1) dan ayat (4) UndangUndang Dasar Negara Republik Indonesia Tahun 1945 (UUD NRI 1945) yang menurut Jimly Asshiddiqie dinyatakan "Tidak ada pembangunan berkelanjutan tanpa lingkungan hidup sebagai unsur utamanya, dan tidak ada wawasan lingkungan tanpa pembangunan berkelanjutan". ${ }^{3}$

Dari pernyataan tersebut pembangunan nasional diselengarakan berdasarkan pembangunan berkelanjutan dan berwawasan lingkungan sehingga pemerintah sebagai penyelengara kekuasaaan negara mempunyai kewajiban dan menjadi tanggung jawab bersama seluruh warga negara Indonesia berdasarkan UUD NRI 1945.

Sehubungan dengan hal tersebut, sebagai landasan operasional pemerintah telah menerbitkan Undang-Undang Nomor 26 Tahun 2007 tentang Penataan Ruang (UU No. 26 Tahun 2007) merupakan serangkaian proses penyempurnaan terhadap substansi Undang- 
Undang No. 24 Tahun 1992 dan Undang-Undang No. 32 Tahun 2009 tentang Perlindungan dan Pengelolaan Lingkungan Hidup (UU No. 32 Tahun 2009).

Menarik untuk digarisbawahi kedua undangundang ini dengan merujuk bagian konsideran maupun materi muatannya menekankan tata pemerintahan yang baik mencakup aspek partisipatif, transparan, akuntabilitas dan otonomi daerah. Sehubungan dengan hal tersebut, mengemuka pola interaksi antara penataan ruang dengan perlindungan dan pengelolaan lingkungan hidup ke dalam strategi pembangunan. Hal tersebut dipahami sematamata untuk mencegah terjadinya dampak negatif yang lebih besar atas rusaknya alam dan lingkungan.

Selaras dengan hal tersebut, merujuk lampiran Undang-Undang No. 17 Tahun 2007 tentang Rencana Pembangunan Jangka Panjang Nasional 2005-2025 menjelaskan tata ruang Indonesia saat ini dalam kondisi krisis. Krisis tata ruang terjadi karena pembangunan yang dilakukan di suatu wilayah masih sering dilakukan tanpa mengikuti rencana tata ruang, tidak mempertimbangkan keberlanjutan dan daya dukung lingkungan, serta tidak memerhatikan kerentanan wilayah terhadap terjadinya bencana alam. Selain itu, sering terjadi konflik pemanfaatan ruang antarsektor dengan penyebab utama adalah belum diacunya perundangan penataan ruang sebagai payung kebijakan pemanfaatan ruang bagi semua sektor dan lemahnya penerapan hukum berkenaan dengan pemanfaatan ruang. ${ }^{4}$

Permasalahan pemanfaatan ruang juga berbenturan dengan kebutuhan akan pasokan listrik terkait dengan wilayah atau area pembangunan pembangkit listrik, yang beberapa terkendala karena wilayah eksplorasi terletak di kawasan hutan. Pada sisi yang lain secara implisit Rencana Pembangunan Jangka Menengah 2005-2009 telah memprioritaskan pembangunan ketenagalistrikan nasional yang ditujukan untuk memulihkan jaminan ketersediaan tenaga listrik nasional. ${ }^{5}$

Sejalan dengan prioritas tersebut pemerintah turut melibatkan badan usaha milik negara, daerah dan swasta sebagaimana termuat dalam program percepatan pembangunan pembangkit listrik $10.000 \mathrm{MW}$ tahap I didasarkan atas Peraturan Presiden No. 71 Tahun 2006 yang menugaskan Kepada PT Perusahaan Listrik Negara untuk melakukan percepatan pembangunan tenaga listrik yang menggunakan batu bara.

Dalam ketentuan tersebut terdapat rencana pembangunan pembangkit listrik tenaga uap (PLTU) mencakup 10 (sepuluh) PLTU di Pulau Jawa salah satunya adalah PLTU 1 (satu) Jawa Barat ${ }^{6}$ dan 25 (dua puluh lima) PLTU di luar Jawa Bali. Kendati telah dicanangkan sejak tahun 2006 dan semula direncanakan selesai dalam waktu tiga tahun berdasarkan ketentuan di atas dalam implementasinya mengalami keterlambatan penyelesaian di tahun 2012.

4 Kementerian Perencanaan Pembangunan Nasional, Rencana Pembangunan Jangka Panjang Nasional 2005-2025 (Jakarta: Kementerian Perencanaan Pembangunan Nasional, 2005), hlm.26.

5 Kementerian Perencanaan Pembangunan Nasional, Rencana Pembangunan Jangka Menengah Nasional 20052009 (Jakarta: Kementerian Perencanaan Pembangunan Nasional, 2005), hlm.21.

6 Ditandai dengan pengoperasian PLTU Cirebon unit 1 kapasitas 1x660MW oleh PT Cirebon Energi Prasana berlokasi di Desa Kanci, Kecamatan Astanajapura, Kabupaten Cirebon. 
Dalam perkembangan tahap I ini menurut Dewan Energi Nasional baru mencapai 74\% (status s.d. 2014), ${ }^{7}$ lebih lanjut merujuk Rencana Pembangunan Jangka Menengah Nasional 20102014 memprioritaskan di bidang energi dengan menggunakan energi alternatif atau energi terbarukan panas bumi sehingga mencapai $2.000 \mathrm{MW}$ pada 2012 dan $5.000 \mathrm{MW}$ pada $2014 .^{8}$

Terkait capaian tersebut selanjutnya termuat dalam program percepatan pembangunan listrik 10.000 tahap II berdasarkan Peraturan Presiden No. 4 Tahun 2010 yang menugaskan PT Perusahaan Listrik Negara untuk melakukan percepatan pembangunan tenaga listrik yang menggunakan energi terbarukan, batu bara dan gas, yang kemudian ditindaklanjuti oleh Kementerian Energi dan Sumber Daya Mineral dengan menerbitkan Peraturan Menteri Energi dan Sumber Daya Mineral No. 21 Tahun 2013 tentang Perubahan Kedua Atas Peraturan Menteri Energi No. 15 Tahun 2010 tentang Daftar Proyek-Proyek Percepatan Pembangunan Pembangkit Tenaga Listrik Yang Menggunakan Energi Terbarukan, Batu Bara dan Gas Serta Transmisi Terkait. ${ }^{9}$

Terkait dengan pemanfaatan ruang yang digunakan sebagai lokasi PLTP Gunung Ciremai secara adminstrasi melintasi wilayah Kabupaten Kuningan dan Kabupaten Majalengka. ${ }^{10}$

Berdasarkan Keputusan Menteri Energi Sumber Daya dan Mineral yang menjadi dasar eksplorasi hanya menjelaskan secara umum lokasi dimaksud. ${ }^{11}$ Dari beberapa lokasi tersebut, mengacu data potensi dari Dinas Sumber Daya Mineral dan Pertambangan Kabupaten Kuningan terdapat di tiga titik panas bumi yakni di Kecamatan Cigandamekar Desa Sangkanhurip dengan prospek geothermal berada pada aktivitas vulkanik aktif dan instrusi andesit pada batuan sedimen tersier, potensinya seluas 10 $\mathrm{km}$ persegi dengan temperatur reservoir sekitar 210 derajat celcius dan bisa dimanfaatkan sebesar 25 MW. Potensi prospek di Kecamatan Kramatmulya Desa Pajambon temperatur reservoir sekitar 210 derajat celcius dengan luas sekitar $20 \mathrm{~km}$ persegi dan bisa dimanfaatkan tenaga listriknya sebesar 135 MW. Selain itu, potensi terduga di Kecamatan Jalaksana Desa Ciniru sebesar 75 MW. ${ }^{12}$

Problematika muncul terkait status kawasan Gunung Ciremai yang ditetapkan sebagai Taman Nasional dan sebagai kawasan pelestarian alam yang termasuk dalam kawasan hutan konservasi pada tahun 2004 berdasarkan Peraturan

Dewan Energi Nasional Republik Indonesia, Ketahanan Energi Indonesia 2014 (Jakarta: Dewan Energi Nasional Republik Indonesia, 2014), hlm.58.

8 Kementerian Perencanaan Pembangunan Nasional, Buku I Prioritas Nasional, Rencana Pembangunan Jangka Menengah Nasional 2010-2014, 2010, hlm.57.

9 Selanjutnya merujuk lampiran III dalam ketentuan ini, menetapkan proyek pembangkit listrik panas bumi Gunung Ciremai sebesar 2x55 MW dan proyek pembangkit listrik tenaga uap Jawa 1 sebesar 1x1000MW.

10 Berdasarkan Keputusan Menteri Energi Sumber Daya dan Mineral No. 1153 K/30/MEM/2011 diketahui memiliki luas 24.330 ha dengan cadangan terduga 150 Mwe.

11 merujuk lampiran IV dalam Peraturan Daerah Kabupaten Kuningan No. 26 Tahun 2011 tentang Rencana Tata Ruang Wilayah Kabupaten Kuningan Tahun 2011-2031 menetapkan beberapa wilayah kerja panas bumi diantaranya yaitu: (1) Kecamatan Cigandamekar Desa Sangkanhurip; (2) Kecamatan Jalaksana Desa Ciniru; (3) Kecamatan Kramatmulya Desa Pajambon; (4) Kecamatan Subang Desa Subang; (5) Kecamatan Cibingin Desa Ciangir.

12 Website/internet: Administrator, Potensi Panas Bumi, http://www.kuningankab.go.id/sumber-daya-alam/ potensi-panas-bumi (di akses 2 Desember 2014). 
Menteri Kehutanan No. 424/Menhut-11/ 2004 tertanggal 19 Oktober 2004. Pembahasan terkait dengan penentuan Wilayah Kerja Pertambangan (WKP) Panas Bumi Gunung Ciremai pernah dilakukan pada tanggal 20 Oktober $2010^{13}$ yang dihadiri oleh perwakilan dari Dinas Energi dan Sumber Daya Mineral Provinsi Jawa Barat dan Dinas Sumber Daya Air dan Pertambangan Kab. Kuningan, disepakati bahwa calon WKP Gunung Ciremai tidak ada yang masuk ke wilayah Kawasan Taman Nasional Gunung Ciremai". ${ }^{14}$

Namun mengacu Zonasi Taman Nasional Gunung Ciremai (TNGC), tertanggal 23 April 2012 sebagaimana telah diubah pada tanggal 30 Maret 2015 menyatakan sebaliknya kawasan TNGC mengandung panas bumi yaitu di Lembah Cilengkrang ${ }^{15}$ memiliki cadangan terduga mencapai $135 \mathrm{MW}$, sehingga pada lokasi tersebut, dimungkinkan adanya ekplorasi sesuai dengan peraturan perundangan yang berlaku di kawasan konservasi. ${ }^{16}$ Namun jika dibandingkan dengan Pasal 38 Undang-Undang No. 41 Tahun 1999 sebagaimana telah diubah dengan Undang-Undang No. 19 Tahun 2004 tentang Kehutanan secara jelas dinyatakan bahwa penggunaan kawasan hutan untuk kepentingan pembangunan di luar kegiatan kehutanan hanya dapat dilakukan di dalam kawasan hutan produksi dan hutan lindung. ${ }^{17}$

Ketidaksetujuan adanya perubahan pemanfaatan ruang juga disampaikan oleh masyarakat dengan mengajukan gugatan di Pengadilan
Negeri Usaha Negara Bandung di tahun 2016 akibat dari adanya perluasan PLTU unit 1 Cirebon berdasarkan Peraturan Kabupaten Cirebon No. 17 Tahun 2011 tentang Rencana Tata Ruang Wilayah Kabupaten Cirebon Tahun 2011-2031 hanya menetapkan Kecamatan Astanajapura sedangkan Kecamatan Mundu bukan wilayah yang diperuntukan untuk PLTU, walaupun secara administrasi PLTU unit 1 Cirebon terletak di dua desa yaitu Desa Kanci, Kecamatan Astanajapura dan Desa Waruduwur Blok Kandawaru, Kecamatan Mundu, Kabupaten Cirebon, Propinsi Jawa Barat.

Beranjak dari latar belakang masalah di atas, fokus penelitian ini adalah memberikan analisis hukum atas pemanfaatan ruang di kawasan hutan dan non kawasan kehutanan serta peran serta masyarakat dalam kerangka penataan ruang yaitu: (1) Bagaimana upaya pemerintah melakukan harmonisasi hukum terkait pemanfaatan ruang atas pemanfaatan energi panas bumi untuk keperluan tenaga listrik di kawasan hutan koservasi? (2) Bagaimana peran serta masyarakat dalam penegakan hukum berkenaan perluasan dari PLTU unit 1 Cirebon?

\section{B. Metode Penelitian}

Merujuk latar belakang permasalahan di atas, penelitian hukum ini menggunakan metode yuridis normatif yang pada dasarnya meneliti kaidah-kaidah hukum dan asas-asas hukum. ${ }^{18}$ Selain itu difokuskan pada data hukum

\footnotetext{
13 Dituangkan dalam Berita Acara Pembahasan Batas WKP Panas Bumi Gunung Ciremai No.542/12-Pebum/2010.

14 Website/internet: "Balai Taman Nasional Gunung Ciremai," Siaran Pers, http://tngciremai.com/2014/03/ siaran-pers/ (di akses 2 Maret 2015).

15 Lembah Cilengkrang sebagaimana dimaksud berada di Kecamatan Kramatmulya Desa Pajambon.

16 Buku (4 orang atau lebih penulis): Balai Taman Nasional Gunung Ciremai, Zonasi Taman Nasional Gunung Ciremai, 2015. hlm.11.

17 Website/internet: "Balai Taman Nasional Gunung Ciremai," Siaran Pers, http://tngciremai.com/2014/03/ siaran-pers/ (di akses 2 Maret 2015).

18 Soerjono Soekanto, Penelitian Hukum Normatif; Suatu Tinjauan Singkat (Jakarta: Rajawali, 1985$),$ hlm. 15.
} 
(sumber-sumber hukum) dan persepsi para pemangku kepentingan yang diungkap melalui wawancara serta pengamatan lapangan secara sekilas.

Penelitian ini dapat memperjelas keterkaitan antara kebijakan umum sebagaimana tertuang dalam rencana pembangunan, rencana tata ruang dan pemerintahan daerah berkenaan pengarusutamaan asas-asas umum pemerintahan yang baik terkait peruntukan, penggunaan dan pemanfaatan ruang dengan lahan disaat bersamaan ditengarai menurunnya kualitas kehidupan dan daya dukung lingkungan.

Seluruh rangkaian kegiatan penelitian, dilaksanakan selama kurun waktu 3 tahun sejak tanggal 1 Januari 2014 sampai dengan 26 April 2017 dengan lokasi penelitian di dua wilayah Provinsi Jawa Barat. Pemilihan kedua lokasi penelitian tersebut didasarkan pada pertimbangan dan alasan didasarkan pada penganekaragaman penggunaan energi tenaga listrik yang masih di dominasi oleh energi fosil: Batu bara sebesar 50\% (26 Gigawatt elektrik $(G W e)^{19}$ diimbangi pengusahaan panas bumi sebagai energi terbarukan dan bahan bakar utama pembangkit listrik.

\section{Pembahasan}

Jamak diketahui Provinsi Jawa Barat berkontribusi secara nasional sebagai penyedia air baku, penyedia bahan pangan, penyedia lahan dan infrastruktur pendukung diantaranya pembangkit tenaga listrik batu bara (PLTU) dan pembangkit tenaga listrik panas bumi (PLTP) didukung dengan luas wilayah $37.3173,97$ hektar ${ }^{20}$ sedangkan luas hutan seluas 816.603 ha berdasarkan Surat Keputusan Menteri Kehutanan 195/Kpts-II/2003 terdiri dari: Hutan konservasi seluas 132.180 ha; Hutan lindung 291.306 seluas ha; Hutan produksi seluas 202.965 ha; Hutan produksi terbatas seluas 190.152 ha menyimpan kurang lebih 43 manifestasi wilayah kerja panas bumi dan tersebar di 11 kabupaten dengan total potensi mencapai 6.101 Megawatt elektrik (Mwe).

Energi ketenagalistrikan merupakan komoditas primer strategis yang cenderung selalu meningkat dan mempengaruhi pembangunan berkelanjutan nasional terkait pengelolaanya memerlukan kehatihatian, ketelitian dan kebijaksanaan dengan memperhatikan daya dukung dan daya tampung lingkungan mengacu rencana tata ruang yang telah ditetapkan hal ini dimaksudkan agar terjadi sinergi dan efisiensi pembangunan, sekaligus menghindari kemungkinan terjadinya perselisihan pemanfaatan ruang antar sektor yang berkepentingan dan dampak merugikan pada masyarakat.

Apabila, pertumbuhan konsumsi listrik mencapai sekitar 8-9\% per tahun ${ }^{21}$ pada saat bersamaan belum diimbangi kegiatan produksi untuk keperluan pasokan tenaga listrik nasional akan memicu kondisi kekurangan energi ketenagalistrikan diiringi kenaikan harga listrik yang mempengaruhi turunnya daya beli masyarakat di tahun 2018 di samping itu

19 Pusat Teknologi Sumber Daya Energi dan Industri Kimia dan Badan Pengkajian dan Penerapan Teknologi, Pengembangan Energi Untuk Mendukung Industri Hijau (Jakarta: Pusat Teknologi Sumber Daya Energi dan Industri Kimia dan Badan Pengkajian dan Penerapan Teknologi, 2016), hlm.16.

20 Badan Pusat Statistik Provinsi Jawa Barat, “Luas Wilayah Jawa Barat Menurut Kabupaten/Kota," https://jabar. bps.go.id/linkTabelStatis/view/id/10 (di akses pada tanggal 20 Oktober 2016).

21 Kementerian Energi dan Sumber Daya Mineral, Kajian Isu-Isu Sektor Laporan Akhir Analisis Isu-Isu Sektor Energi dan Sumber Daya Mineral (Jakarta : Kementerian Energi dan Sumber Daya Mineral ,2012), hlm.4. 
masih terdapat 2.519 desa belum memperoleh jaringan listrik di Indonesia. ${ }^{22}$

Untuk mengatasi kebutuhan tenaga listrik yang terus meningkat, maka pemerintah membuka kesempatan kepada semua pihak, termasuk pemerintah daerah dan swasta serta para pelaku usaha untuk berpartisipasi sebagaimana termuat dalam Peraturan Presiden No. 2 Tahun 2015 tentang Rencana Jangka Panjang Nasional 2015-2019.23

Selanjutnya diturunkan dalam rencana usaha penyediaan tenaga listrik 2015-2024 berdasarkan Keputusan Menteri Energi dan Sumber Daya Mineral Nomor : 74 K/21/ MEM/2015 tentang Pengesahan Rencana Usaha Penyediaan Tenaga Listrik PT Perusahaan Listrik Negara (Persero) tahun 2015 sampai dengan 2024 sebagaimana telah diubah dengan Keputusan Menteri Energi dan Sumber Daya Mineral Nomor : 1415 K/20/MEM/2017 tentang Pengesahan Pengesahan Rencana Usaha Penyediaan Tenaga Listrik PT Perusahaan Listrik Negara (Persero) tahun 2017 sampai dengan 2026 menunjang alokasi penyediaan energi listrik sebesar 35.000 Mwe dan jaringan transmisi sepanjang $48.000 \mathrm{~km}$.

Mengenai hal tersebut kendati tidak secara eksplisit dinyatakan dalam Undang-undang No. 23 Tahun 2014 tentang Pemerintahan Daerah Merujuk penjelasan Pasal 67 hurur f, yang dimaksud dengan program strategis nasional adalah program yang ditetapkan Presiden sebagai program yang memiliki sifat strategis secara nasional dalam upaya meningkatkan pertumbuhan dan pemerataan pembangunan serta menjaga pertahanan dan keamanan dalam rangka meningkatkan kesejahteraan masyarakat.

Dari pengertian program strategis nasional di atas terkait dengan Peraturan Presiden No. 4 Tahun 2016 sebagaimana telah diubah dengan Peraturan Presiden No. 14 Tahun 2017 tentang Percepatan Pembangunan Infrastruktur Ketenagalistrikan memuat alokasi penyediaan energi listrik dan jaringan transmisi di atas dalam rangka peningkatan pemenuhan kebutuhan tenaga listrik.

\section{Upaya Harmonisasi Hukum}

Pengusahaan panas bumi di Provinsi Jawa Barat bukanlah hal yang baru sebelumnya sebagaimana diatur Undang-Undang No. 27 Tahun 2003 tentang Panas Bumi. Namun, merujuk materi muatan peraturan ini menggunakan istilah "Kegiatan penambangan/ pertambangan" membawa konsekuensi tidak dapat diusahakan dalam kawasan hutan konservasi karena Pasal 38 Undang-Undang No. 41 Tahun 1999 jo. 19 Tahun 2004 tentang Kehutanan menyebutkan penggunaan kawasan hutan untuk kepentingan pembangunan di luar kegiatan kehutanan hanya dapat dilakukan di dalam kawasan hutan produksi dan kawasan hutan lindung.

Selanjutnya, dalam Undang-Undang No. 5 Tahun 1990 tentang Konservasi dan Sumber Daya Alam dan Ekosistemnya serta Peraturan Pemerintah No. 28 Tahun 2011 tentang Pengelolaan Kawasan Suaka Alam dan Kawasan Pelestarian Alam sebelumnya mengatur

22 Website/internet: Tanpa Nama, "Pemerintah Dorong Swasta Kembangkan Listrik Perdesaan," http://www.djk. esdm.id/index.php/detail-berita?=4210 (di akses 26 Maret 2015).

23 Kementerian Perencanaan Pembangunan Nasional, Buku IAgenda Pembangunan Nasional, Rencana Pembangunan Jangka Menengah Nasional 2015-2019 (Jakarta: Kementerian Perencanaan Pembangunan Nasional, 2015), hlm. 114. 
bahwa dalam kawasan hutan konservasi dapat dilakukan melalui kegiatan pemanfaatan usaha jasa lingkungan, namun belum optimal ${ }^{24}$ saat ini telah diubah dengan Peraturan Pemerintah No. 108 Tahun 2015.

Di beberapa wilayah diantaranya pembangkit listrik tenaga panas bumi (PLTP) CisolokCisukarame, Taman Nasional Gunung HalimunSalak, Kabupaten Sukabumi dan PLTP Gunung Ciremai, Taman Nasional Gunung Ciremai, Kabupaten Kuningan, Provinsi Jawa Barat sebagaimana dinyatakan pada Daftar ProyekProyek Percepatan Pembangunan Pembangkit Tenaga Listrik Yang Menggunakan Energi Terbarukan, Batubara dan Gas Serta Transmisi Terkait dalam Peraturan Menteri Energi Sumber Daya Mineral Nomor 32 Tahun 2014 tentang Perubahan Ketiga Atas Peraturan Menteri Energi dan Sumber Daya Mineral No. 15 Tahun 2010.

Adanya kecenderungan kendala peraturan perundang-undangan bersinggungan dengan penataan ruang atas alih fungsi hutan baik yang memenuhi prosedur melalui skema tukarmenukar, pinjam pakai, dan pelepasan kawasan hutan, maupun praktek non-prosedural telah marak terjadi di lapangan. ${ }^{25}$

Selain itu, tidak dapat dilepaskan terhadap strategi pemerintah menata kembali pengaturan otonomi daerah berkenaan pembagian kewenangan dan urusan perihal pengusahaan panas bumi dengan kehutanan sebagai salah satu sumber daya alam strategis dalam penyediaan energi listrik.

Terkait hal tersebut di tahun 2011, Kementerian Energi dan Sumber Daya Alam
Mineral (KESDM) dengan Kementerian Kehutanaan (KEMENHUT) menandatangani Nota Kesepahaman Nomor. 7662/05/ MEM.S/2001 dan Nomor NK.16/Menhut-II/201 tentang Koordinasi dan Percepatan Perizinan Pengusahaan Panas Bumi pada Kawasan Hutan Produksi, Kawasan Hutan Lindung dan Kawasan Konservasi. Lebih lanjut, KESDM berupaya merevisi Undang-Undang No. 27 Tahun 2003 saat ini dicabut dan dinyatakan tidak berlaku melalui Undang-Undang No. 21 Tahun 2014 tentang Panas Bumi (UU 21 Tahun 2014), hingga penelitian ini disusun pada awalnya KEMENHUT dengan Dewan Kehutanan Nasional sejak 2010 telah mendorong merevisi UndangUndang No. 5 Tahun 1990 tentang Konservasi Sumber Daya Alam Hayati dan Ekosistemnya. Namun, saat ini telah masuk dalam daftar program legislasi nasional tahun 2015-2019 atas pemrakarsa Dewan Perwakilan Rakyat dan belum diundangkan.

Di saat bersamaan Kementerian Dalam Negeri melalui Direktur Jenderal Otonomi Daerah merevisi Undang-Undang No. 32 Tahun 2004 yang saat ini telah dicabut dan dinyatakan tidak berlaku dengan Undang-Undang No. 23 Tahun 2014 sebagaimana telah diubah dengan Perubahan Pertama dalam UU No. 02 Tahun 2015 dan Perubahan Kedua dalam UU No. 09 Tahun 2015 tentang Pemerintahan Daerah. Mengacu serangkaian perubahan dalam materi muatan UU No. 21 Tahun 2014 dengan UU No. 23 Tahun 2014, secara faktual terdapat perubahan penarikan kekuasaan/kewenangan

24 Tuti Ermawati dan Siwage Dharma Negara, Pengembangan Industri: Energi Alternatif Studi Kasus Energi Panas Bumi Indonesia (Jakarta : Lembaga Ilmu Pengetahuan Indonesia Press, 2014), hlm.57.

25 Badan Perencanaan Pembangunan Nasional, Direktorat Kehutanan dan Konservasi Sumber Daya Air, Peran Sektor Kehutanan Dalam Pembangunan Nasional dan Regional (Jakarta: Badan Perencanaan Pembangunan Nasional ,2014), hlm.4. 
atas pemanfaatan tidak langsung panas bumi untuk keperluan tenaga listrik.

Hal ini menunjukan resentralisasi sebagian atau sentralisasi mikro yang pada kenyataannya menjauhkan pemerintah daerah kabupaten sebagai pihak berwenang untuk menangani masalah-masalah yang ada di daerah ${ }^{26}$ dilatarbelakangi permasalahan sedikitnya 23 proyek pembangkit PLTP terancam mangkrak karena pembangunannya tidak signifikan.

Terkait perubahan peraturan tersebut, dari satu sisi capaian target pembangunan PLTP di wilayah kerja panas bumi (WKP) Cisolok-Cisukarame merupakan proyek hasil lelang setelah terbitnya UU No. 27 Tahun 2003 tentang Panas Bumi dan ditetapkan berdasarkan Keputusan Menteri Energi dan Sumber Daya Mineral (Kepmen ESDM) No. 1937 K-30-MEM-2007 seluas 15.580 ha dengan nilai proyek US\$127 serta termasuk dalam Nota Kesepahaman KESDM dengan KEMENHUT 2011, di tahun 2016 Cisolok-Cisukarame dapat memulai kegiatan eksplorasi.

Sedangkan di sisi lain, belum diiringi pengusahaan di WKP Gunung Ciremai dalam hal ini Kementerian Lingkungan dan Kehutanan menerbitkan Peraturan Menteri Lingkungan Hidup dan Kehutanan Nomor: P.46/Menlhk/ Setjen/Kum.1/5/2016 tentang Pemanfaatan Jasa Lingkungan Panas Bumi Pada Kawasan Taman Nasional, Taman Hutan Raya dan Taman Wisata Alam.

Terkait penggunaan kawasan hutan tersebut di awali penerbitan izin panas bumi oleh Menteri Energi dan Sumber Daya Mineral kemudian Menteri Lingkungan Hidup dan Kehutanan dalam bentuk izin pemanfaatan jasa lingkungan panas bumi terdiri atas: (a) Eksplorasi; (b) Eksploitasi; (c) Pemanfaatan. Sejalan dengan hal tersebut capaian Rencana Pembangunan Jangka Menengah Nasional berdasarkan Peraturan Presiden No. 2 Tahun 2015 dan Peraturan Presiden No. 4 Tahun 2016 sebagaimana telah diubah dengan Peraturan Presiden 14 Tahun 2017 tentang Percepatan Pembangunan Infrastruktur Ketenagalistrikan mengalami kendala terkait persoalan ketidaksesuaian peruntukan tata ruang sebagaimana tertuang dalam Rencana Tata Ruang Propinsi dan Kabupaten.

Terkait kendala di atas, Pemerintah melakukan peninjauan kembali terhadap Peraturan Pemerintah No. 26 Tahun 2008 (PP No. 26 Tahun 2008) sebagaimana telah diubah dengan Peraturan Pemerintah No. 13 Tahun 2017 tentang Rencana Tata Ruang Wilayah Nasional (PP No. 13 Tahun 2017).

Namun, Pemerintah tidak mengubah Peraturan Pemerintah secara keseluruhan, tetapi mengamandemenkan beberapa pasal yang belum selesai dan menambahkan beberapa proyek pembangunan infrastruktur baru dalam bentuk lampiran pada revisi Peraturan Pemerintah ini.

Berkenaan perubahan tersebut, apabila diperbandingkan kedua ketentuan di atas, Kabupaten Kuningan termasuk dalam kawasan andalan Cirebon-Indramayu-MajalengkaKuningan (Ciayumaja Kuningan) dengan sektor unggulan berdasarkan PP No. 26 Tahun 2008 terdiri dari: (1) Pertanian; (2) Industri; (3) Perikanan; (4) Pertambangan. Beberapa sektor

26 Badan Pembinaan Hukum Nasional, Laporan Akhir Pengkaijan Hukum Tentang Pembagian Kewenangan Pembagian Kewenangan Pusat dan Daerah Dalam Pengelolaan Laut (Jakarta: Badan Pembinaan Hukum Nasional, 2015), hlm.4. 
unggulan tersebut selanjutnya mengalami perubahan dengan penambahan sektor yakni: (5) Panas Bumi; (6) Minyak dan Gas Bumi lebih lanjut khususnya sektor panas bumi telah memasuki tahap pengembangan sebagaimana dinyatakan dalam lampiran IX tentang kawasan andalan dalam PP No. 13 Tahun 2017.

Sejalan dengan hal tersebut sektor panas bumi merupakan salah satu bagian dalam sistem jaringan energi nasional mencakup jaringan infrastruktur ketenagalistrikan.

Mengenai jaringan infrastruktur ketenagalistrikan lebih lanjut diatur di antara Pasal 40 dan Pasal 42 PP No. 13 Tahun 2017 disisipkan satu pasal yakni Pasal 40A menyatakan "Pembangkitan tenaga listrik tercantum dalam lampiran VA merupakan bagian tidak terpisahkan dari Peraturan Pemerintah ini".

Merujuk lampiran VA mengenai jaringan infrastruktur pembangkitan tenaga listrik khususnya di Jawa Barat dalam Peraturan Pemerintah ini tidak menyatakan adanya pembangkitan listrik di Kabupaten Kuningan di samping itu Taman Nasional Gunung Ciremai termasuk dalam lampiran VIII tentang kawasan lindung sebagaimana dinyatakan dalam PP No. 26 Tahun 2008 dan PP No. 13 Tahun 2017.

Selanjutnya mengenai pengembangan sektor panas bumi dalam PP No. 26 Tahun 2008 belum mengatur kawasan yang akan dipergunakan selanjutnya hal ini diatur dalam Pasal 63 PP No. 13 Tahun 2017 ditetapkan dalam kawasan budi daya salah satunya terdiri atas kawasan peruntukan panas bumi.

Kemudian terkait penetapan kawasan peruntukan panas bumi didasarkan pada beberapa kriteria sebagaimana diatur dalam Pasal 68A ayat (1) menyatakan:

a. memiliki sumber energi panas yang terkandung di dalam air panas, uap air, dan batuan bersama mineral ikutan dan gas lainnya yang secara genetik semuanya tidak dapat dipisahkan dalam suatu sistem panas bumi;

b. merupakan wilayah yang dapat dimanfaatkan untuk pemanfaatan langsung panas bumi dan pemanfaatan tidak langsung panas bumi

Lebih lanjut, Pasal 68A ayat (2) mengatur kriteria teknis untuk kawasan peruntukan kawasan panas bumi di atas ditetapkan oleh menteri yang tugas dan tanggung jawabnya di bidang panas bumi. Kemudian mengenai pengusahaan panas bumi di taman nasioal Pasal 101 ayat (2) PP 13 Tahun 2017 menyatakan perturan zonasi untuk taman nasional disusun dengan memperhatikan:

a. pemanfaatan ruang untuk wisata alam, penelitian dan pengembangan, serta ilmu pengetahuan;

b. pemanfaatan ruang untuk penyimpanan atau penyerapan karbon, pemanfaatan air, energi air, energi panas, dan energi angin;

c. pemanfaatan ruang untuk pemanfaatan sumber plasma nutfah sebagai penunjang budi daya dan pemanfaatan tumbuhan, satwa liar, serta koleksi keanekaragaman hayati;

d. pemanfaatan tradisional oleh masyarakat setempat;

e. ketentuan pelarangan kegiatan budi daya di zona inti; dan

f. ketentuan pelarangan kegiatan budi daya yang berpotensi mengurangi tutupan vegetasi atau terumbu karang di zona penyangga.

Lebih lanjut, dalam Pasal 110A menjelaskan Peraturan zonasi untuk kawasan peruntukan panas bumi disusun dengan memperhatikan: 
a. pemanfaatan untuk pengusahaan panas bumi dilakukan berdasarkan prinsip konservasi dan keberlanjutan;

b. ketentuan pelarangan alih fungsi lahan menjadi lahan budi daya selain pengusahaan panas bumi yang meliputi kegiatan survey pendahuluan, eksplorasi, eksploitasi, dan pemanfaatan.

Beranjak dari beberapa Pasal di atas tersebut, kendati Kabupaten Kuningan tidak termasuk dalam jaringan infrastruktur pembangkitan tenaga listrik berdasarkan Pasal $114 A$ ayat (1) menjelaskan mengenai pemberian izin pemanfaatan didasarkan pada PP 13 Tahun 2017 ini. Kemudian menteri terkiat memberikan rekomendasi pemanfaatan ruang sebagaimana dimaksud Pasal 114 ayat (2)

Adapun setelah aturan tersebut diterbitkan, evaluasi akan dilakukan pemerintah dalam lima tahun ke depan sejak penerapannya. Evaluasi tersebut antara lain mencakup pengerjaan sejumlah proyek infrastruktur yang disertakan ke dalam Peraturan Pemerintah tersebut.

Merujuk uraian di atas, dalam konteks negara kesatuan penerapan asas sentralisasi dan desentralisasi dalam organisasi negara tidak bersifat dikotonomi melainkan berkelanjutan, artinya pemerintah pusat tidak mungkin menyelengarakan semua urusan pemerintahan yang diserahkan dan mempengaruhi penyelengaraan otonomi berdasarkan Pasal 18 ayat (5) UUD NRI 1945.

Berkenaan dengan hal ini, urusan sumber daya mineral mencakup energi terbarukan panas bumi dan ketenagalistrikan yaitu pemanfaatan tidak langsung panas bumi merupakan urusan pemerintahan konkuren pilihan yang pelaksanaan ditarik menjadi urusan pemerintah pusat dengan menyisakan satu urusan mengenai pemanfaatan langsung panas bumi untuk keperluan non ketenagalistrikan kepada daerah kabupaten sebagai pelaksana perintah dan arahan pemerintah pusat.

\section{Peran Serta Masyarakat}

Sebelumnya Peraturan da No. 17 tahun 2011 tentang RTRW Kabupaten Cirebon Tahun 20112031. Telah disosialisasikan bertempat di Off Room Bappeda Kabupaten Cirebon pada tanggal 27-28 Desember 2011, telah dilaksanakan sosialisasi Rencana Tata Ruang Wilayah (RTRW) Kabupaten Cirebon Tahun 2011-2031. Acara sosialisasi di buka oleh Bupati Cirebon Bpk. H.Drs.Dedi Supardi, MM., dan Paparan oleh Ir. Tatit Konitat, M.M selaku Kepala Bidang Fisik dan Prasarana. Undangan di hadiri oleh perwakilan SKPD dan Kecamatan-Kecamatan di Kabupaten Cirebon.

Seiring pembangunan berbasis kebijakan energi wilayah timur Cirebon akan dibangun PLTU tahap dua yang sudah berjalan satu bulan kendati rancangan Perda perubahan atas Perda Kabupaten Cirebon Nomor 17 Tahun 2011 tentang Rencana Tata Ruang dan Tata Wilayah Kabupaten Cirebon tahun 2011-2031 masih dibahas bersama dengan Dewan Perwakilan Rakyat Daerah Cirebon terkait memasukkan Desa Kanci Kulon, Kecamatan Astanajapura dan Desa Waru Duwur, Kecamatan Mundu Kabupaten Cirebon ke dalam kawasan industri listrik.

Sebagaimana diketahui peruntukan wilayah Kecamatan Mundu sesuai Perda Kab. Cirebon No. 17 Tahun 2011 adalah sebagai berikut: (1) Kecamatan Mundu diperuntukan untuk sistem pedesaan; (2) Kecamatan Mundu diperuntukan untuk sistem perkotaan khususnya peranan pedagang kaki lima Lemahabang; (3) Kecamatan Mundu diperuntukan untuk perlintasan jalur kereta api Cirebon-Semarang; 
(4) Kecamatan Mundu diperuntukan untuk perlintasan jalur kereta api Cirebon-Yogyakarta; (5) Kecamatan Mundu diperuntukan untuk rencana pengembangan stasiun kereta api Stasiun Luwung dan Stasiun Waruduwur; (6) Kecamatan Mundu diperuntukan untuk lintasan jaringan transmisi listrik meliputi Saluran Udara Tegangan Tinggi (SUTT); (7) Kecamatan Mundu diperuntukan untuk pelestarian dan pemanfaatan situ Patok untuk irigasi dan pariwisata; (8) Kecamatan Mundu diperuntukan untuk jalur evakuasi bencana alam gelombang pasang, abrasi dan banjir; (9) Kecamatan Mundu diperuntukan untuk kawasan resapan air. Khususnya di Desa Sinarancang seluas 4 (empat) hektar; (10) Kecamatan Mundu diperuntukan untuk pertanian Holtikultura sayuran besar seluas 10 (sepuluh) hektar (Ha); (11) Kecamatan Mundu diperuntukan untuk peternakan besar seluas 10 (sepuluh) hektar; (12) Kecamatan Mundu diperuntukan untuk perikanan budidaya air tawar, perikanan budidaya laut, perikanan budidaya air tambak, industri pengolahan perikanan dan pelabuhan pendaratan; (13) Kecamatan Mundu diperuntukan untuk industri soun.

Terkait hal tersebut, Pasal 65 UndangUndang No. 26 Tahun 2007 tentang Penataan Ruang telah mengamanatkan peran masyarakat baik dalam hal penyusunan, pemanfaatan dan pengendalian pemanfaatan ruang kemudian ketentuan lebih lanjut diatur dalam Peraturan Pemerintah No. 68 Tahun 2010 tentang Bentuk dan Tata Cara Peran Serta Masyarakat Dalam Penataan Ruang. Di samping itu Pasal 4 Undang-Undang Nomor 14 tahun 2008 tentang Keterbukaan Informasi Publik telah jelas memberikan amanat kepada badan publik untuk mengumumkan informasi publik yang bersifat berkala kepada masyarakat dan informasi tersebut disampaikan kepada masyarakat dengan cara yang mudah dijangkau oleh masyarakat. Tidak hanya itu, cara menyampaikannya pun harus menggunakan bahasa yang mudah dimengerti, karena setiap individu mempunyai daya jelajah pemahaman yang berbeda-beda.

Adapun masyarakat terdampak pembangunan PLTU I Cirebon baru mengetahui adanya rencana tersebut di wilayahnya yaitu pada 22 September 2016 dari seorang warga bernama Wahyu Widiarto melalui situs web www.jbic.go.jp. Sedangkan izin lingkungan dituangkan dalam Surat Keputusan Kepala Badan Penanaman Modal dan Perizinan Terpadu Provinsi Jawa Barat Nomor : 660/09/19.1.02.0/BPMPT/2016 tentang Izin Lingkungan Kegiatan Pembangunan dan Operasional PLTU Kapasitas 1x1000MW Cirebon Kecamatan Astanajapura dan Kecamatan Mundu Daerah Kabupaten Cirebon tertanggal 11 Mei 2016atas dasar Keputusan Ketua Komisi Penilai Amdal Kabupaten Cirebon Nomor: 660.1/51/KPA/KA-ANDAL/2016 tentang Persetujuan Kerangka Acuan Rencana Kegiatan Pembangunan dan Operasi Pembangkit Listrik Tenaga Uap (PLTU) Cirebon kapasitas 1×1000 Mw.

Hal ini melatarbelakangi gugatan sejumlah masyarakat Desa Kanci Kulon, Kecamatan Astanajapura didasarkan pada angka (1) di atas sebagai obyek sengketa pada 28 Desember 2016.

Perkembangan saat ini PT Cirebon Energi Prasarana mengajukan dan mengacu pengumuman Nomor : 660.1/3163/Bid-I/2017 tentang Permohanan Perubahan Izin Lingkungan Kegiatan Pembangunan dan Operasi Operasi Pembangkit Listrik Tenaga Uap (PLTU) Cirebon kapasitas 1x1000 Mwe, Provinsi Jawa Barat kendati berdasarkan putusan pengadilan 
tata usaha negara Bandung Nomor : 124/G/ LH/2016/PTUN-BDG telah membatalkan Surat Keputusan Kepala Badan Penanaman Modal dan Perizinan Terpadu Provinsi Jawa Barat Nomor : 660/09/19.1.02.0/BPMPT/2016, tertanggal 02 Juni 2017.

Sehubungan dengan hal tersebut, sebagaimana telah diuraikan sebelumnya mengenai beberapa beberapa rencana pembangunan umum dan sektoral khususnya ketenagalistrikan peran serta masyarakat dapat dikatakan tidak menjadi hal utama kendati beberapa peraturan perundang-undangan di atas telah memberikan jaminan akan hal tersebut dikarenakan capaian adalah program strategis nasional.

\section{Penutup}

Dalam pemanfaatan ruang baik di kawasan hutan dan non kawasan hutan pada pelaksanaannya masih bersifat bisa dirubah tanpa sebelumnya melakukan revisi atas rencana Tata Ruang Wilayah Kabupaten baik Kuningan dengan Kuningan di Propinsi Jawa Barat sebagaimana diakomodir dalam Rencana Tata Ruang Wilayah Nasional. Dalam hal ini pelaku usaha telah memperoleh izin lokasi untuk pembangkit listrik tenaga uap. Sedangkan pengusahaan energi panas bumi, pemerintah telah melakukan proses harmonisasi hukum di tingkat peraturan utama dan peraturan pelaksana secara parsial baik dari aspek kewenangan antara pemerintah pusat, daerah propinsi dan daerah kabupaten terkait ketenagalistrikan dan perubahan cara pandang terhadap kawasan hutan konservasi dapat dilakukan kegiatan pembangunan melalui skema izin pemanfatan jasa lingkungan panas bumi. Di samping itu peran serta masyarakat pemanfaatan ruang tidak menjadi hal utama dikarenakan capaian adalah program strategis nasional.

Untuk efektifnya kegiatan pengusahaan panas bumi di kawasan hutan konservasi pemerintah perlu melakukan perubahan undang-undang tentang konservasi sumber daya alam dan ekosistemnya. Selanjutnya terkait peran serta masyarakat perlu dilakukan pelbagai pendekatan dengan melibatkan tidak hanya instansi daerah melainkan bersama-sama dengan instansi pusat dengan pelaku usaha.

\section{Daftar Pustaka}

\section{Buku}

Badan Perencanaan Pembangunan Nasional, Direktorat Kehutanan dan Konservasi Sumber Daya Air, Peran Sektor Kehutanan Dalam Pembangunan Nasional dan Regional (Jakarta: Badan Perencanaan Pembangunan Nasional , 2014).

Balai Taman Nasional Gunung Ciremai, Zonasi Taman Nasional Gunung Ciremai (Jakarta: Balai Taman Nasional Gunung Ciremai, 2015).

Badan Perencanaan Pembangunan Nasional, Buku I Agenda Pembangunan Nasional, Rencana Pembangunan Jangka Menengah Nasional 2015-2019 (Jakarta: Badan Perencanaan Pembangunan Nasional , 2015).

Dewan Energi Nasional Republik Indonesia, Ketahanan Energi Indonesia 2014 (Jakarta: Dewan Energi Nasional Republik Indonesia, 2014).

Jimly Asshiddiqie, Green Constitution: Nuansa Hijau Undang-Undang Negara Republik Indonesia Tahun 1945 (Jakarta: Rajawali Pers, 2010).

Kementerian Perencanaan Pembangunan Nasional, Buku I Prioritas Nasional, Rencana Pembangunan Jangka Menengah Nasional 2010-2014 (Jakarta: Kementerian Perencanaan Pembangunan Nasional , 2010).

Kementerian Perencanaan Pembangunan Nasional, Rencana Pembangunan Jangka Panjang Nasional 2005-2025 (Jakarta: Kementerian Perencanaan Pembangunan Nasional , 2005).

Kementerian Perencanaan Pembangunan Nasional, Rencana Pembangunan Jangka Menengah 
Nasional 2005-2009 (Jakarta: Kementerian Perencanaan Pembangunan Nasional , 2005).

Otto Sumarwoto, Ekologi, Lingkungan Hidup dan Pembangunan (Jakarta: Djambatan, 1994).

Peter Mahmud Marzuki, Penelitian Hukum, (Jakarta: Kencana, 2008).

Pusat Teknologi Sumber Daya Energi dan Industri Kimia dan Badan Pengkajian dan Penerapan Teknologi, Pengembangan Energi Untuk Mendukung Industri Hijau, (Jakarta: Pusat Teknologi Sumber Daya Energi dan Industri Kimia dan Badan Pengkajian dan Penerapan Teknologi ,2016).

Soerjono Soekanto, Penelitian Hukum Normatif; Suatu Tinjauan Singkat (Jakarta: Rajawali, 1985).

Tuti Ermawati dan Siwage Dharma Negara, Pengembangan Industri: Energi Alternatif Studi Kasus Energi Panas Bumi Indonesia (Jakarta: Lembaga Ilmu Pengetahuan Indonesia Press, 2014).

\section{Makalah/Artikel/Laporan/Hasil Penelitian}

Badan Pembinaan Hukum Nasional, Laporan Akhir Pengkaijan Hukum Tentang Pembagian Kewenangan Pembagian Kewenangan Pusat dan Daerah Dalam Pengelolaan Laut (Jakarta: Badan Pembinaan Hukum Nasional, 2015).

Kementerian Energi dan Sumber Daya Mineral, Kajian Isu-Isu Sektor Laporan Akhir Analisis Isu-Isu Sektor Energi dan Sumber Daya Mineral (Jakarta: Kementerian Energi dan Sumber Daya Mineral, 2012).
Daud Silalahi, "Pembangunan Berkelanjutan Dalam Rangka Pengelolaan (Temasuk Perlindungan) Sumber Daya Alam yang Berbasis Pembangunan Sosial dan Ekonomi" (Makalah disampaikan pada Seminar Pembangunan Hukum Nasional VIII, Badan Pembinaan Hukum Nasional, Denpasar, 14-18 April 2003).

\section{Internet}

Ferial, "Protensi Panas Bumi Jawa Barat", http:// ebtke.esdm.go.id/post/2011/10/27/198/ potensi.prioritas.panas.bumi.jawa.barat (di akses 27 Oktober 2015)

Jafar Soddik, "Pengumuman Lelang Wilayah Kerja Panas Bumi (WKP) Gunung Ciremai", http:// ebtke.esdm.go.id/post/2016/11/16/1434/ pengumuman.lelang.wilayah.kerja.panas.bumi. wkp.gunung.ciremai (di akses 16 November 2016)

Balai Taman Nasional Gunung Ciremai, Siaran Pers, http://tngciremai.com/2014/03/siaran-pers/ (di akses 2 Maret 2015)

Badan Pusat Statistik Provinsi Jawa Barat, "Luas Wilayah Jawa Barat Menurut Kabupaten/Kota", https://jabar.bps.go.id/linkTabelStatis/view/ id/10 (di akses pada tanggal 20 Oktober 2016)

Tanpa Nama, "Pemerintah Dorong Swasta Kembangkan Listrik Perdesaan", http://www. djk.esdm.id/index.php/detail-berita? $=4210$ (di akses 26 Maret 2015)

Administrator, "Potensi Panas Bumi", http://www. kuningankab.go.id/sumber-daya-alam/potensipanas-bumi (di akses 2 Desember 2014) 